THE KURUME MEDICAL JOURNAL

Vol.35, p. 207-209, 1988

\title{
Effects of Etretinate on Epidermal Langerhans Cell
}

\author{
OSAMU MORI, HIROSHI HACHISUKA, HIROFUMI NOMURA, \\ KEIJI OKUBO AND YOICHIRO SASAI \\ Department of Dermatology, Kurume University School of Medicine Kurume, 830 Japan \\ Received for publication November 4, 1988
}

\begin{abstract}
Summary: The effect of etretinate, applied systemically, on epidermal Langerhans cells was studied. The numbers and shapes of Langerhans cells were observed on split epidermis, and the percentage of Langerhans cells in whole epidermal cells was determined with a flow cytometrial system. On an epidermal sheet, the number of Langerhans cells changed biphasically, first the number increased, then decreased, and finally it returned to normal. The percentage of Langerhans cells was drastically decreased by etretinate and the low value was maintained during the etretinate treatment. This difference may be due to a decrease in the cell surface marker.
\end{abstract}

Key words: Langerhans cells-epidermal sheet-flow cytometry-retinoidIa-antigen

\section{Introduction}

Epidermal Langerhans cells (LCs), situated in the midepidermis, maintain constant shapes and numbers. Various stimuli such as UV irradiation, corticosteroids and tape striping, can change the number and shape of the LCs (Lessard et al. 1968; Aberer et al. 1981; Berman et al. 1983). The number of stumptail monkey epidermal LCs was reduced during the topical application of retinoic acid onto the epidermal sheet (Hachisuka and Uno, 1987). The present paper describes the effect of etretinate on the percentage of Ia antigenpositive cells in whole epidermis by flow cytometry, and compares these to the numbers in the split epidermis of guinea pig skin.

\section{Materials and Methods}

Hartley strain guinea pigs, weighing $500 \mathrm{~g}$, were used in the study. Retinoid treatment was performed by oral administration of etretinate (Ro-10-9359, Roche, Basel, Swizerland) at a concentration of $10 \mathrm{mg} / \mathrm{kg}$ in $1 \mathrm{ml}$ of peanut oil. The guinea pigs were separated into 6 groups and were given etretinate, daily, for 30 days. Every 5 th day, the dorsal skin of 3 guinea pigs from each group was shaved with an electric clipper. The remaining hair was removed with a hair remover. Animals were sacrificed by cervical dislocation, and the dorsal skin was removed with a keratotome set at $0.5 \mathrm{~mm}$. The skin sample was incubated in $20 \mathrm{mM}$ EDTA $\left(\mathrm{pH} \mathrm{7.3)}\right.$ at $37^{\circ} \mathrm{C}$ for an hour. The epidermal sheet was separated from the dermis with fine forceps.

Reprint requests to: Osamu Mori, M.D., Department of Dermatology, Kurume University School of Medicine, 67 Asahimachi, Kurume, 830 Japan 


\section{Flow cytometry:}

The split epidermis was incubated in $0.25 \%$ trypsin-Hanks solution ( $\mathrm{pH} 7.3$ ) for $20 \mathrm{~min}$ at room temperature. After filtration through a nylon mesh, the isolated cells were washed twice with Hanks solution and suspended in phosphate-buffered saline (PBS), $\mathrm{pH} 7.2$, at a concentration of $5 \times 10^{6} \mathrm{cells} / \mathrm{ml}$. $100 \mu \mathrm{l}$ of the cell suspension was incubated with $5 \mu 1$ of OKIa1 (Ortho, NJ) (Stingl et al. 1978) for 30 min at $4^{\circ} \mathrm{C}$. Myeloma ascites was used instead of OKIal for the negative control. After washing with PBS, the cells were further incubated with FITC-conjugated goat antimouse IgG (Tago, CA) for $30 \mathrm{~min}$ at $4^{\circ} \mathrm{C}$. After again washing with $\mathrm{PBS}$, the Ia antigen-positive cells were counted with a flow cytometrial system with Spectrum III (Ortho, NJ). Evaluation for threshold on the histogram was determined by comparing the fluorescence to the background fluorescence from the myeloma ascites. The threshold for the negative control was adjusted to below 2.0\%. Each determination was duplicated and was based on more than $1 \times 10^{3}$ cells per sample.

\section{Epidermal sheet:}

The split epidermis was washed three times in PBS for $15 \mathrm{~min}$ and fixed with precooled acetone at $-20^{\circ} \mathrm{C}$ for $40 \mathrm{~min}$. Af ter washing three times with PBS, the tissue was incubated with OKIal (1:40 dilution) at room temperature for $60 \mathrm{~min}$. After another washing with PBS, the tissue was incubated with peroxidase-conjugated goat anti-mouse IgG (Tago, CA; 1:20 dilution) for $60 \mathrm{~min}$ at room temperature. Then the tissue was rinsed with $\mathrm{PBS}$, and placed in $\mathrm{DAB}-\mathrm{H}_{2} \mathrm{O}_{2}$ solution for $5 \mathrm{~min}$ and mounted on a glass slide, after washing with PBS. Ia positive-cell counts were performed using a reticle fitted into the eyepiece of the microscope. The number of cells per $\mathrm{mm}^{2}$ was counted in 10 fields.

\section{Results}

\section{Flow cytometry:}

The ratio of Ia positive cells to whole epidermal cells was shown in Fig. 1. In untreated animals, $6.7 \%$ of the epidermal cells were Ia antigen-positive. The ratios of Ia antigen-positive cells in etretinate treated guinea pigs were drastically reduced to $1.9 \%$ on 5 th day. This low value was maintained for 25 days. Epidermal sheet:

As shown in Fig. 1, the number of Ia positive cells was increased from the 5 th to the 15th day, and then decreased at the 20th day. The dendritic processes were shortened or disappeared, and the perikaryon became oval or round. The population and morphology of the Ia positive-cells returned to normal during the etretinate treatment.

\section{Histology:}

In hematoxylin and eosin sections, the epidermis had granular and squamous layers that were increased in thickness ap-

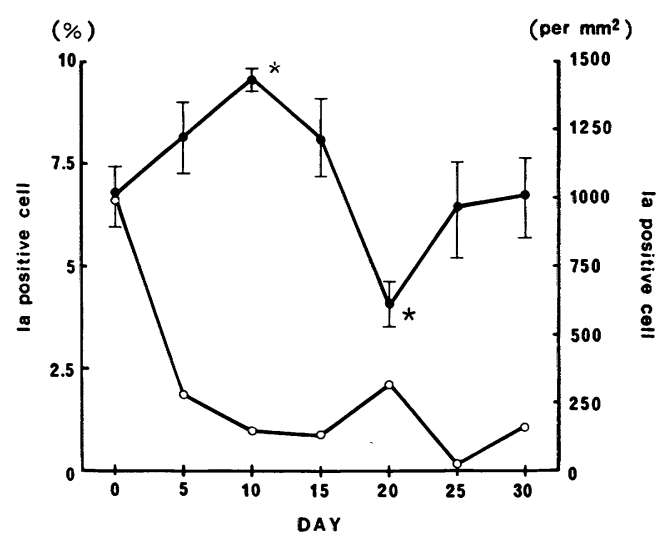

Fig. 1. Time course of changes in the population of Ia positive cells during systemic application of etretinate, illustrated as, $\bigcirc-\circ$, percentage of Ia antigen-positive cells in whole epidermal cells, and $\bullet-\bullet$, number of Ia antigen-positive cells in the epidermal sheet. 
proximately twice, by the 15th day after beginning etretinate administration, and this thickness was maintained throughout the experiment.

\section{Discussion}

The present study demonstrates that the systemic administration of etretinate causes biphasic changes in the number of epidermal Ia antigen-positive cells in the epidermal sheet. An increase of the granular and squamous layers was observed, even by the 5 th day, and continued up to the 30th day. In the epidermal sheet, the number of Ia antigen-positive cells first increased, and then decreased. Finally, the number returned to the normal level. The increase in the number of Ia antigenpositive cells may be due to migration from the dermis or to proliferation within the epidermis (Kanerva et al. 1983). On the other hand, there are several possible explanations for the reduction of Ia antigenpositive cells. First, there may be an actual decrease in the cell number. Second, the cells may have been affected functionally, as a result of alterations of the Ia antigen on the cell surface. Third, the decrease could be the result of an enhanced migration of LCs from the epidermis. In an earlier paper, the number of Ia antigen-positive cells in the epidermal sheet were counted. The increase or decrease was not expressed as a percentage of all the epidermal cells because the epidermis became acanthotic during etretinate treatment. In the present study, acanthosis was histologically observed from the 5 th day. Therefore it seemed important to determine whether the change in the ratio between Ia antigen-positive cells and epidermal cells coincided with the changes in the epidermal sheet. In contrast to the results on the epidermal sheet, the percentage of Ia antigen-positive cells in whole epidermal cells was reduced at the 5th day and this low value was maintained to the 30th day. When an increase of LCs was observed in the epidermal sheet, the percentage of cells was still decreased. This difference is probably due to a decreased fluorescence of Ia antigen-positive cells below the threshold for flow cytometry. Since the Ia antigen is stable against trypsin (Stingl et al. 1978), the reduction of Ia antigen-positive cells is not due to the enzyme. Etretinate at a concentration of $10 \mathrm{mg} / \mathrm{kg}$, which is ten times higher than the clinical dose, could destroy the Ia antigens on the LCs. Although this study does not exclude the possibility that further changes of LCs could be induced by longer administration, etretinate is assumed to have a toxic effect on the epidermal LCs.

\section{References}

Aberer, W., Schuler, G., Stingl, G., Honigsmann, H. and WolfF, K. (1981). Ultraviolet light depletes surface markers of Langerhans cells. J. Invest. Dermatol. 76, 202-210.

Berman, B., France, D.S., Martinelli, G.P. and Hass, A. (1983). Modulation of expression of epidermal Langerhans cell properties following in situ exposure to glucocorticosteroids. J. Invest. Dermatol. 80, 168-171.

HACHISUKA, H. and UNO,H. (1987). Effects of retinoic acid on the epidermal Langerhans cells and $\beta$-glucuronidase activity in macague skin. Am. J. Dermatopathol. 9, 316-323.

Kanerva, L., Lauharanta, J. and Niemi, K-M. (1983). Electron microscopic observations of mitotic Langerhans' cells as possible sign of retinoic-induced stimulation. J. Cutan. Pathol. 10, 138-143.

Lessard, R. J., Wolff, K. and Winkelmann, R. K. (1968). The disappearance and regeneration of Langerhans cells following epidermal injury. J. Invest. Dermatol. 50, 171-179.

Stingl, G., Katz, S. I., Shevach, E. M., WolffSchreiner, E. and Green, I. (1978). Detection of Ia antigens on Langerhans cells in guinea pig skin. J. Immunol. 129, 570-578. 